\title{
New Procedure to Fortify Fluid Milk and Derivatives with Iron: A Comparative Study in Mice
}

\author{
José R. Boccio, Marcela B. Zubillaga, Ricardo A. CARo, \\ Carlos A. Gotelli, ${ }^{1, *}$ Mariano J. Gotelli, ${ }^{1}$ \\ and Ricardo WEILL ${ }^{2}$ \\ Radioisotope Laboratory, Physics Department, School of Pharmacy and \\ Biochemistry, University of Buenos Aires, Buenos Aires, Argentina \\ ${ }^{1}$ Center of Toxicological Research, San Pedrito 220, \\ 1406 Buenos Aires, Argentina \\ ${ }^{2}$ Center of Research and Development, La Serenisima, \\ Buenos Aires, Argentina
}

(Received March 1, 1995)

Summary It is known that the fortification of milk and its derivatives with iron has been recognized as a worldwide necessity, since the deficiency of this element produces different metabolic disorders. With this purpose, we have studied the iron absorption in mice after the administration of fluid milk and yogurt with $\mathrm{FeSO}_{4}$ stabilized by microencapsulation with soy lecithin (SFE-171) or with $\mathrm{FeSO}_{4}$, both labeled with ${ }^{59} \mathrm{Fe}$, which was used in the same experimental conditions for comparative purposes. The absorption of iron is influenced by the presence of some additives which usually are ingested together with milk, such as cacao, coffee, tea, "Argentine green herbs tea or maté" or cereals. The experimental results demonstrate that the iron absorption from SFE-171 is $(12.3 \pm 2.9) \%$, whereas that from $\mathrm{FeSO}_{4}$ is $(7.7 \pm 2.7) \%$, this difference is highly significant at $p<0.01$. In all the cases, groups of 25 mice each were used to increase the statistical robustness of the experimental results. On the other hand, it could be demonstrated that the presence of $10 \% \mathrm{w} / \mathrm{v}$ cacao $\left(\right.$ Nesquik $^{\mathrm{TM}}$ ) increases the iron absorption in both cases, whereas $1 \% \mathrm{w} / \mathrm{v}$ cacao (Nesquik ${ }^{\mathrm{TM}}$ ) and mate has no influence on the iron absorption if SFE-171 is used. Cereals (Nestum ${ }^{\mathrm{TM}} 3$ cereals), yogurt and other additives like tea and coffee, for different reasons, decrease the absorption of this element.

Key Words milk, fortification, ferrous sulfate, mice, absorption, iron

Iron defficiency has been recognized as one of the major nutritional problems in the world. Parr and Fjeld (1) analyzed the situation and pointed out that

\footnotetext{
* To whom correspondence should be addressed.
} 
radioisotopic methods are suitable to determine iron absorption and that RIA or ELISA are useful for the measurement of ferritin. In Argentina, iron defficieny has been principally observed in poor children who showed low blood hemoglobin concentration and ferritin and low FEP values indicating deposit depletion (2). Dietary iron defficiency is known to produce metabolic and physiological disorders, principally in children, nursing babies, and pregnant women (3). For these reasons, there is growing interest in the world to fortify fluid milk and derivatives with iron, in consideration of the fact that milk is consumed in mass quantities, and that it has an easy access for many people, and because it is generally the only ingested food at the beginning of human life.

Different procedures have been utilized to fortify fluid milk with iron (4) or other products such as bread (5), cereals (6) and powder milk (2). However, if fluid milk is fortified with iron by ordinary methods, there are changes of color, taste or flavor, as well as precipitation or flotation of different products (6). In the specific case of the addition of ferrous sulfate to fluid milk, the procedure determines a strong alteration of the mentioned sensorial characteristics. In order to avoid this inconvenience, a ferrous sulfate stabilized by microencapsulation with soy lecithin, called SFE-171*, has been developed recently. Fluid milk fortified with this product shows no alteration of its sensorial characteristics with regard to ordinary milk, as consistently determined by a triangular test method developed by "La Serenísima."

In the present paper, we study the iron absorption in mice after the administration of fluid milk or yogurt with the addition of ferrous sulfate or SFE-171, both labeled with ${ }^{59} \mathrm{Fe}$. On the other hand, it is known that after childhood, milk is seldom taken as fluid milk alone. The additives used vary among different countries or even in the same country according to different feeding habits. The absorption of iron from milk will be increased or decreased according to the addition of different products which usually are ingested together with it, such as coffee, tea, “Argentine green herbs tea or maté," cacao $\left(\right.$ Nesquik $^{\mathrm{TM}}$ ) or cereals $\left(\right.$ Nestum $^{\mathrm{TM}} 3$ cereals). For this reason, we studied also the iron absorption from milk with $\mathrm{FeSO}_{4}$ or with SFE-171 when they are mixed with these additives. It should be noted that phytates, tannins and phosphates, as well as other substances, decrease markedly the absorption of iron (7).

\section{EXPERIMENTAL}

Animals. We used 400 female mice from the Swiss strain, weighing from 30 to $40 \mathrm{~g}$. They were distributed in 16 groups of 25 mice, each group was housed in a stainless steel cage ( $315 \mathrm{~mm}$ by $445 \mathrm{~mm}$ by $240 \mathrm{~mm}$ of height) with a stainless steel grated floor and a collecting tray of the same material, which prevents the

* Japanese patent $\# 178712 / 94$; SFE stands for stabilized ferrous sulfate in spanish; 171 is the number of the experiment. 
excrements from coming in contact with the animals. They were maintained with free access to water and fed on a normalized diet having the following composition: proteins, $20.0 \% \mathrm{w} / \mathrm{w}$ minimum; fat, $2.0 \% \mathrm{w} / \mathrm{w}$ minimum; fiber, $11.0 \% \mathrm{w} / \mathrm{w}$ maximum; ashes, $10.0 \% \mathrm{w} / \mathrm{w}$ maximum; calcium carbonate, $1.5 \% \mathrm{w} / \mathrm{w}(\mathrm{Ca}: 0.6 \% \mathrm{w} / \mathrm{w})$; phosphorus, $0.7 \% \mathrm{w} / \mathrm{w}$; iron, $50 \mathrm{ppm}(8)$; and moisture, $13.0 \% \mathrm{w} / \mathrm{w}$. The animals were maintained with a 12 -h light-dark cycle throughout the experiments.

Administration of the preparations under study. For the preparation of the materials to be administered to the animals, we used pasteurized whole milk "La Serenísima" brand, fortified by the addition of $\mathrm{FeSO}_{4}$ or by stabilized ferrous sulfate which was microencapsulated using soy lecithin (SFE-171); both preparations were labeled with ${ }^{59} \mathrm{Fe}$ and boiled for $30 \mathrm{~min}$. In the first product the radioactivity concentration was $122.1 \mathrm{kBq}$ per ml, whereas in the second case it was $96.2 \mathrm{kBq}$ per $\mathrm{ml}$ at the time of preparation. The ${ }^{59} \mathrm{Fe}$ (NEN, DuPont, Catalogue No. NEZ 037) had a specific activity at the beginning of the work of $777 \mathrm{MBq}$ per $\mathrm{mg}$, which was lowered during the preparation of the products to $2.4 \mathrm{MBq}$ per mg for SFE-171 and 3.1 MBq per mg for $\mathrm{FeSO}_{4}$. To carry out the comparative study we added to either product $10 \%$ or $1 \% \mathrm{w} / \mathrm{v}$ of cacao $\left(\mathrm{Nesquik}^{\mathrm{TM}}\right)$ or $5 \% \mathrm{w} / \mathrm{v}$ of coffee, tea, maté or cereals (Nestum ${ }^{\mathrm{TM}} 3$ cereals). The yogurt was prepared incorporating the Lactobacillus bulgaricus to the milk containing $\mathrm{FeSO}_{4}$ or SFE-171. Before the administration of either preparation, the mice were deprived of any solid food for $10 \mathrm{~h}$, which was then given $1 \mathrm{~h}$ after the ingestion of the different preparations.

The products under study were administered using a syringe coupled to a plastic gastric tube which made it possible to standardize the intake volume $(0.1$ $\mathrm{ml}$ ). The mass of iron administered to each mouse was $4 \mu \mathrm{g}$ and the activity of ${ }^{59} \mathrm{Fe}$ was $9.62 \mathrm{kBq}$ for SFE-171 and $12.21 \mathrm{kBq}$ for $\mathrm{FeSO}_{4}$.

Radioactivity measurements. The absolute activities of each preparation were determined by means of an ionization chamber (RADX Model 255 Remote). The activity retained in the mice as a function of time was measured by means of a gamma spectrometer with a $5 \mathrm{~cm} \times 5 \mathrm{~cm} \mathrm{NaI}(\mathrm{T} 1)$ crystal with optimal electronic conditions. The measured activity was always compared to a ${ }^{60} \mathrm{Co}$ standard in order to detect any eventual efficiency fluctuation. The efficiency of the measurements (2.4\%) remained constant throughout the experiments.

The iron absorption was determined by measuring the ${ }^{59} \mathrm{Fe}$ radioactivity in the mice, using a whole-body geometry, introducing each animal in a covered lucite box, the size of which was adapted to the animal size and to the detector geometry. In this way, it was possible to minimize detection errors during the measurements, which could be attributed to eventual movements of the animal. The radioactivity determination of an ${ }^{59} \mathrm{Fe}$ standard in the same geometric and electronic conditions demonstrated the reliability of this technique. Taking into account the measurement efficiency and the ${ }^{59} \mathrm{Fe}$ activity, the mass of absorbed iron was calculated. By this method, the percentage of absorbed iron with regard to the iron administered with the milk could be determined.

Statistical analysis of the experimental results. The data are presented as $\mathbf{M} \pm$

Vol. 41, No. 6, 1995 
SD. To test for differences among all the products under study, we evaluated the results by two-way analysis of variance (ANOVA). We applied the simple effects test for the different levels of the two studied factors. A "post-hoc" test was carried out in order to find the differences between each additive and the milk which was ingested together with it, applying the Dunnett test. $p<0.01$ was taken as the level of significance (9).

\section{RESULTS}

Figure 1 shows the percentage of iron remaining in the whole body (retention) as a function of time, in mice which received fluid milk fortified with $\mathrm{FeSO}_{4}$ or with SFE-171, both labeled with ${ }^{59} \mathrm{Fe}$. The final part of the curve is extrapolated to the initial time in order to calculate the absorption percentage, eliminating the influence of the physical decay of ${ }^{59} \mathrm{Fe}$.

Curves of similar shape, are obtained with all the preparations; in all of them, the iron absorption was calculated as shown in Fig. 1, in order to standardize the experimental results.

The bar graph in Fig. 2 shows the iron absorption percentage of each group. As it can be observed in all the cases, the absorption of the preparations fortified with SFE-171 was higher than that obtained with $\mathrm{FeSO}_{4}$.

For the purpose of comparing the obtained iron absorption results, Tables 1 and 2 summarize the statistical analysis carried out.

In Table 1, we compare each preparation fortified with $\mathrm{FeSO}_{4}$ with the same preparation fortified with SFE-171.

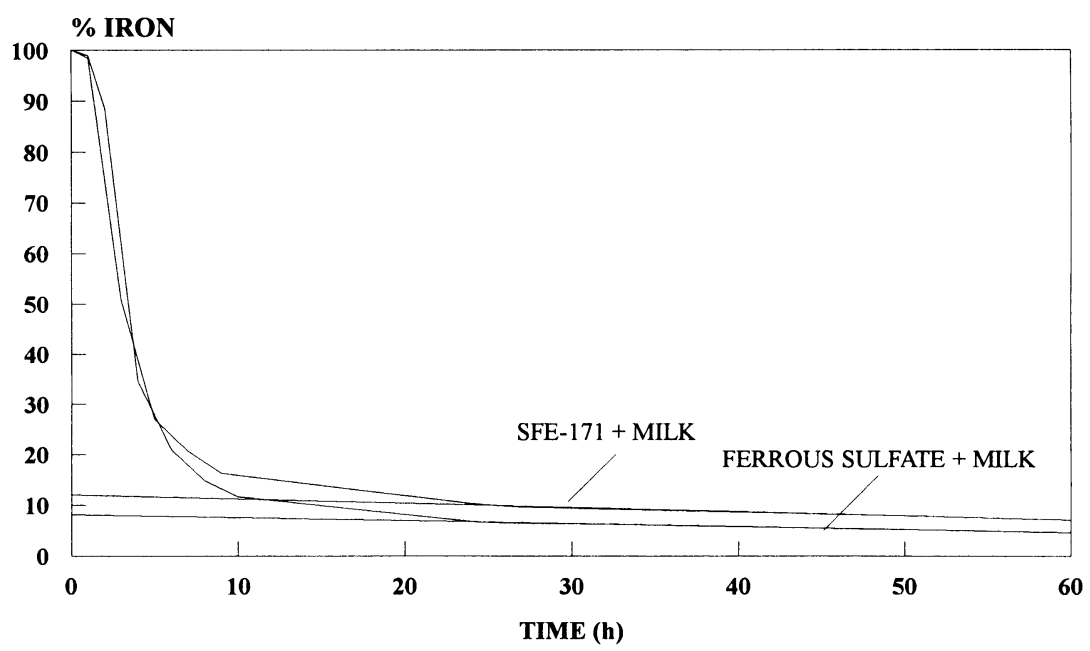

Fig. 1. Percentage of iron retention as a function of time. Notice that the curves are extrapolated to time $=0$ to eliminate the physical radioisotopic decay. 


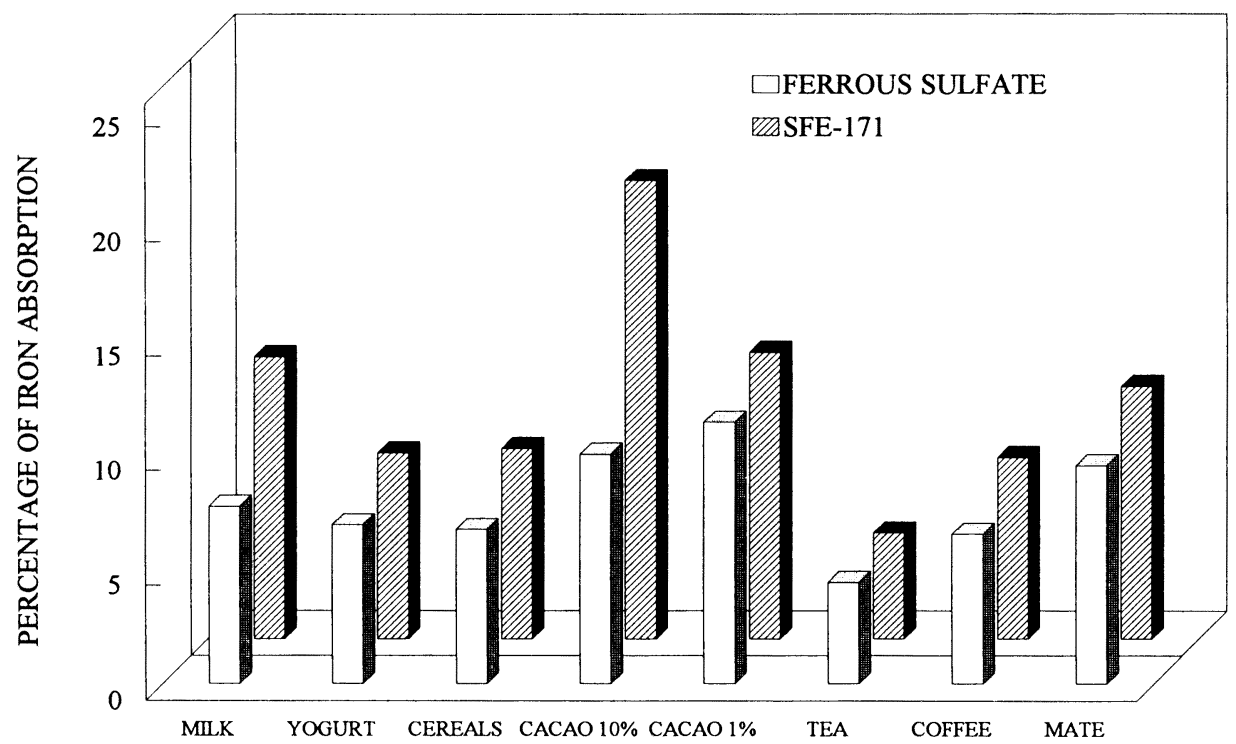

Fig. 2. Percentage of iron absorption for each product at the end of the experiment.

Table 1. Statistical comparison between the iron absorption of each of the products fortified with $\mathrm{FeSO}_{4}$ or with SFE-171.

\begin{tabular}{|c|c|c|}
\hline Studied products & $\begin{array}{l}\text { Absorption } \\
\text { percentage }\end{array}$ & $\begin{array}{c}\text { Difference } \\
\text { Limit: } p<0.01\end{array}$ \\
\hline $\begin{array}{l}\text { Milk }+\mathrm{FeSO}_{4} \\
\text { Milk }+ \text { SFE-171 }\end{array}$ & $\begin{array}{r}7.7 \pm 2.7 \\
12.3 \pm 2.9\end{array}$ & Significant \\
\hline $\begin{array}{l}\text { Cacao } 10 \%+\text { Milk }+\mathrm{FeSO}_{4} \\
\text { Cacao } 10 \%+\text { Milk }+ \text { SFE-171 }\end{array}$ & $\begin{array}{l}10.0 \pm 3.1 \\
20.1 \pm 3.3\end{array}$ & Significant \\
\hline $\begin{array}{l}\text { Cacao } 1 \%+\text { Milk }+\mathrm{FeSO}_{4} \\
\text { Cacao } 1 \%+\text { Milk }+ \text { SFE-171 }\end{array}$ & $\begin{array}{l}11.4 \pm 2.7 \\
12.5 \pm 3.1\end{array}$ & Not significant \\
\hline $\begin{array}{l}\text { Yogurt }+\mathrm{FeSO}_{4} \\
\text { Yogurt }+ \text { SFE-171 }\end{array}$ & $\begin{array}{l}6.9 \pm 2.9 \\
8.1 \pm 3.0\end{array}$ & Not significant \\
\hline $\begin{array}{l}\text { Coffee } 5 \%+\text { Milk }+\mathrm{FeSO}_{4} \\
\text { Coffee } 5 \%+\text { Milk }+ \text { SFE-171 }\end{array}$ & $\begin{array}{l}6.5 \pm 2.0 \\
7.9 \pm 3.1\end{array}$ & Not significant \\
\hline $\begin{array}{l}\text { Tea } 5 \%+\text { Milk }+\mathrm{FeSO}_{4} \\
\text { Tea } 5 \%+\text { Milk }+ \text { SFE-171 }\end{array}$ & $\begin{array}{l}4.4 \pm 2.1 \\
4.6 \pm 1.5\end{array}$ & Not significant \\
\hline $\begin{array}{l}\text { Mate } 5 \%+\text { Milk }+\mathrm{FeSO}_{4} \\
\text { Mate } 5 \%+\text { Milk }+ \text { SFE-171 }\end{array}$ & $\begin{array}{r}9.5 \pm 3.0 \\
11.0 \pm 2.0\end{array}$ & Not significant \\
\hline $\begin{array}{l}\text { Cereals } 5 \%+\text { Milk }+\mathrm{FeSO}_{4} \\
\text { Cereals } 5 \%+\text { Milk }+ \text { SFE-171 }\end{array}$ & $\begin{array}{l}6.7 \pm 3.0 \\
8.3 \pm 2.2\end{array}$ & Not significant \\
\hline
\end{tabular}

Vol. 41, No. 6, 1995 
Table 2. Statistical analysis for iron absorption percentage of SFE-171 milk in comparison to the same milk added with other products. In the same way $\mathrm{FeSO}_{4}$ milk was also compared.

\begin{tabular}{|c|c|c|}
\hline Studied products & $\begin{array}{l}\text { Absorption } \\
\text { percentage }\end{array}$ & $\begin{array}{c}\text { Difference } \\
\text { Limit: } p<0.01\end{array}$ \\
\hline $\begin{array}{l}\text { Cacao } 10 \%+\text { Milk + SFE-171 } \\
\text { Milk + SFE-171 }\end{array}$ & $\begin{array}{l}20.1 \pm 3.3 \\
12.3 \pm 2.9\end{array}$ & Significant \\
\hline $\begin{array}{l}\text { Cacao } 1 \%+\text { Milk + SFE-171 } \\
\text { Milk + SFE-171 }\end{array}$ & $\begin{array}{l}12.5 \pm 3.1 \\
12.3 \pm 2.9\end{array}$ & Not significant \\
\hline $\begin{array}{l}\text { Yogurt }+ \text { SFE-171 } \\
\text { Milk }+ \text { SFE-171 }\end{array}$ & $\begin{array}{r}8.1 \pm 3.0 \\
12.3 \pm 2.9\end{array}$ & Significant \\
\hline $\begin{array}{l}\text { Coffee } 5 \%+\text { Milk }+ \text { SFE- } 171 \\
\text { Milk }+ \text { SFE- } 171\end{array}$ & $\begin{array}{r}7.9 \pm 3.1 \\
12.3 \pm 2.9\end{array}$ & Significant \\
\hline $\begin{array}{l}\text { Tea } 5 \%+\text { Milk + SFE-171 } \\
\text { Milk + SFE-171 }\end{array}$ & $\begin{array}{r}4.6 \pm 1.5 \\
12.3 \pm 2.9\end{array}$ & Significant \\
\hline $\begin{array}{l}\text { Mate } 5 \%+\text { Milk + SFE-171 } \\
\text { Milk + SFE-171 }\end{array}$ & $\begin{array}{l}11.0 \pm 2.0 \\
12.3 \pm 2.9\end{array}$ & Not significant \\
\hline $\begin{array}{l}\text { Cereals 5\%+Milk + SFE-171 } \\
\text { Milk + SFE-171 }\end{array}$ & $\begin{array}{r}8.3 \pm 2.2 \\
12.3 \pm 2.9\end{array}$ & Significant \\
\hline $\begin{array}{l}\text { Cacao } 10 \%+\text { Milk }+\mathrm{FeSO}_{4} \\
\mathrm{Milk}+\mathrm{FeSO}_{4}\end{array}$ & $\begin{array}{r}10.0 \pm 3.1 \\
7.7 \pm 2.7 \\
\end{array}$ & Significant \\
\hline $\begin{array}{l}\text { Cacao } 1 \%+\text { Milk }+\mathrm{FeSO}_{4} \\
\text { Milk }+\mathrm{FeSO}_{4}\end{array}$ & $\begin{array}{r}11.4 \pm 2.7 \\
7.7 \pm 2.7\end{array}$ & Significant \\
\hline $\begin{array}{l}\text { Yogurt }+\mathrm{FeSO}_{4} \\
\mathrm{Milk}+\mathrm{FeSO}_{4}\end{array}$ & $\begin{array}{l}6.9 \pm 2.9 \\
7.7 \pm 2.7\end{array}$ & Not significant \\
\hline $\begin{array}{l}\text { Coffee } 5 \%+\text { Milk }+\mathrm{FeSO}_{4} \\
\mathrm{Milk}+\mathrm{FeSO}_{4}\end{array}$ & $\begin{array}{l}6.5 \pm 2.0 \\
7.7 \pm 2.7\end{array}$ & Not significant \\
\hline $\begin{array}{l}\text { Tea } 5 \%+\text { Milk }+\mathrm{FeSO}_{4} \\
\text { Milk }+\mathrm{FeSO}_{4}\end{array}$ & $\begin{array}{l}4.4 \pm 2.1 \\
7.7 \pm 2.7\end{array}$ & Significant \\
\hline $\begin{array}{l}\text { Mate } 5 \%+\text { Milk }+\mathrm{FeSO}_{4} \\
\text { Milk }+\mathrm{FeSO}_{4}\end{array}$ & $\begin{array}{l}9.5 \pm 3.0 \\
7.7 \pm 2.7\end{array}$ & Not significant \\
\hline $\begin{array}{l}\text { Cereals } 5 \%+\text { Milk }+\mathrm{FeSO}_{4} \\
\text { Milk }+\mathrm{FeSO}_{4}\end{array}$ & $\begin{array}{l}6.7 \pm 3.0 \\
7.7 \pm 2.7\end{array}$ & Not significant \\
\hline
\end{tabular}

In Table 2, the percentage of iron absorption from SFE-171-milk with each additive is compared to that of SFE-171-milk alone. The iron absorption from $\mathrm{FeSO}_{4}$-milk with each additive is also compared to that of $\mathrm{FeSO}_{4}$-milk alone in the same table. 


\section{DISCUSSION}

To evaluate the absorption of $\mathrm{Fe}^{++}$from SFE-171 we used as a reference standard the absorption of $\mathrm{Fe}^{++}$from $\mathrm{FeSO}_{4}$ in the same experimental conditions. Considering that it was necessary to know with a high degree of confidence the differences of the iron absorption among the different products, the experiments were conducted using a large number of mice $(n=25)$.

Table 1 shows that when using milk, there is a significantly higher iron absorption if SFE-171 is used instead of $\mathrm{FeSO}_{4}$. This can be due to the fact that milk contains phosphates and proteins, which may decrease the iron bioavailability (10), an effect that would be diminished or absent in the case of SFE-171, in which iron is stabilized and microencapsulated with soy lecithin.

When $10 \% \mathrm{w} / \mathrm{v}$ Nesquik $^{\mathrm{TM}}$ is added to milk, the iron absorption from SFE-171 is also significantly higher than that observed with $\mathrm{FeSO}_{4}$. It is known that Nesquik $^{\mathrm{TM}}$ has an appreciable lipid (lecithin) content (11), which would stabilize the SFE-171, specially considering that the lecithin content is important in this regard (12).

It should be noted that the addition of $1 \% \mathrm{w} / \mathrm{v}$ Nesquik $^{\mathrm{TM}}$ does not cause any significant difference in the iron absorption from SFE-171-fortified milk.

When comparing the absorption of iron from milk mixed with other products which are usually ingested together, such as tea, coffee, maté or cereals, in each case it can be observed that the differences among the preparations supplied with SFE171 or with $\mathrm{FeSO}_{4}$ are not significant.

Much more complex is the analysis of the iron absorption differences when comparing the values for SFE-171 milk and $\mathrm{FeSO}_{4}$ milk with those using other products mixed with milk (Table 2). The only significant differences in both iron forms were observed with cacao 10\% w/v (increase) and tea 5\% w/v (decrease). The first case can be explained in the same way as mentioned previously. In the case of tea, the difference might be attributed to its content of tannins and polyophenols (13), which form complexes with iron and decrease its absorption. As the tannin and polyphenol concentration decreases (coffee and maté), the iron absorption increases progressively. In the case of cereals, the difference of iron absorption from the $\mathrm{FeSO}_{4}$ is not significant. In the case of SFE-171 the difference is significant. This result may be explained supposing that when cereals mixed with milk and $\mathrm{FeSO}_{4}$ are compared to milk and $\mathrm{FeSO}_{4}$, the iron from $\mathrm{FeSO}_{4}$ was already complexed previously with milk components. In the case of cereals, milk and SFE171 compared to milk with SFE-171 it can be supposed that, since the bioavailability of iron from SFE-171 is greater, when the $\mathrm{Fe}^{++}$arrives in the intestinal lumen and is released, it will be complexed to the fibers and the phytates of the cereals. The decreased iron absorption seen with yogurt could be due to the presence of Lactobacillus bulgaricus in the preparation (14).

This study demonstrates that the fortification of milk with SFE-171 is an 
effective procedure, since iron absorption is greatly enhanced without affecting the sensorial properties of the milk.

Further studies are carried out in order to clarify if this new method for the fortification of milk is equally effective in other animal species as well as in human beings.

We want to acknowledge herewith the kind assistance of Bioch. M. L. Calcagno and Lic. D. Garrido and M. I. Sarchi from the Mathematics Department of the School of Pharmacy and Biochemistry with the statistical analysis carried out in this work.

\section{REFERENCES}

1) Parr, R. M., and Fjeld, C. R. (1994): Salud y nutrición humanas: La ayuda de los isótopos para erradicar el "Hambre escondida." OIEA Boletin, 36, 18-27.

2) Portela, M. L. P. M. (1994): Vitaminas y Minerales en Nutrición, Libreros López Editores, Buenos Aires, Argentina.

3) Goodman \& Gilman's (1990): The pharmacological basis of therapeutics. 8th edition, Pergamon Press Inc. New York, U.S.A.

4) Langini, S., Carbone, N., Galdi, M., Barrio Rendo, M. E., Portela, M. L., Caro, R., and Valencia, M. (1988): Ferric Glycinate iron bioavailability for rats, as determined by extrinsic radioisotopic labelling of infant formulas. Nutr. Rep. Int., 38, 729-735.

5) Cook, J. D., Minnich, V., Moore, C. V., Rasmussen, A., Bradley, W. B., and Finch, C. A. (1973): Absorption of fortification iron in bread. Am. J. Clin. Nutr., 26, 861-872.

6) Hurrel, R. H.: Iron fortification of infant cereals. Personal communication.

7) Hallberg, L., Rossander, L., and Skanberg, A. (1987): Phytates and the inhibitory effect of bran on iron absorption in man. Am. J. Clin. Nutr., 45, 988-996.

8) Heggenauer, J., and Saltman, P. (1976): Bioavailable copper and iron in rat diets. Am. J. Clin. Nutr., 29, 936-938.

9) Sokal, R. R., and Rohlf, F. J. (1969): Biometry, W.H. Freeman and Company, San Francisco, USA.

10) Carmichael, D., Christopher, J., Hegenauer, J., and Saltman, P. (1975): Effect of Milk and Casein on the Absorption of Supplemental Iron in the Mouse and Chick. Am. J. Clin. Nutr., 28, 487-493.

11) Trease, G. E. and Evans, W. C. (1972): Pharmacognosy, Bailliere Tindall, London, U.K.

12) Costanzo, R., De Paoli, T., Ihlo, J. E., Hager, A. A., Farach, H. A., Poole, C. P., Jr., and Knight, J. M. (1994): ESR study of order and dynamics in lecithin liposomes with high cholesterol content. Spectrochim. Acta, 50A, 203-208.

13) Tyler, V. E., Brady, L. R., and Robbers, J. E. (1988): Pharmcognosy, 9th Edition, Lea \& Febiger, Philadelphia, USA.

14) Neilands, J. B., ed. (1974): Microbial Iron Metabolism: A Comprehensive Treatise, Academic Press, Inc., New York, USA. 